Article

\title{
Assessing the Potential of Sustainable Value Chains in the Collaborative Economy
}

\author{
Myriam Ertz ${ }^{1, *(1)}$ and Emine Sarigöllï ${ }^{2}$ \\ 1 LaboNFC, Université du Québec à Chicoutimi; Chicoutimi, QC G7H 2B1, Canada \\ 2 LaboNFC, McGill University; Montreal, QC H3A 1G5, Canada; emine.sarigollu@mcgill.ca \\ * Correspondence: Myriam_Ertz@uqac.ca; Tel.: +1-418-545-5011
}

Received: 28 December 2018; Accepted: 10 January 2019; Published: 14 January 2019

check for updates

\begin{abstract}
The current business paradigm entails a narrow, profit-centered and managerially-focused nature. This article proposes that the study of the collaborative economy necessitates an inevitable shift in the conventional business paradigm and suggests that the institutional school of marketing thought, in general, and the electric theory of marketing, in particular, offers a useful theoretical framework for investigating the theoretical impact of the collaborative economy on the value chain. Uber is used as an illustrative case, on which the electric theory of marketing is applied, to demonstrate how the archetype of the collaborative economy theoretically impacts the value chain and contributes to sustainability in the value chain in the transportation services industry. The study provides further insights in the form of suggestions and propositions for ensuring sustainability in the value chain of collaborative systems.
\end{abstract}

Keywords: sharing economy; collaborative economy; value chain; institutional school; electric theory of marketing; Uber; sustainability; conceptualization; business paradigm; services

\section{Introduction}

Value creation has traditionally been associated with the corporate world. Yet, the collaborative economy (hereafter, $\mathrm{CE}$ ) enables individuals to create value as well, by redistributing or mutualizing resources to producers, governments, or other individuals [1]. The CE creates, therefore, a multiplicity of new value chains, and it is no wonder then that the collaborative market is expected to grow from 14 billion in 2014 to 335 billion USD in 2025 [2]. The CE extends truly the realm of exchanges and markets to levels unmatched before [3]. In line with other theoretically related concepts, such as prosumption [4], shadow work [5], co-creation [6], or service-dominant logic [7], the CE blurs the modernist distinction between the production and distribution world (i.e., provider-centric) and the consumption world (i.e., consumer-centric) [8]. As already suggested, by the authors cited above, this distinction has never been relevant, and is, in fact, even less relevant now, with the advent of a CE.

The CE (re-)acknowledges the more fluid and flexible roles of actors on the market. The CE also disrupts conventional frames of value creation, supply chain configurations, exchange modes, and market frontiers. In light of such conceptual reshaping of our view, an appropriate study of the $\mathrm{CE}$ and its theoretical impact on the value chain necessitates the adaptation of a broader framework of analysis than the one commonly employed in business scholarly research, including environmental studies and industrial ecology research. Such a broad framework will not only enable exploration of the theoretical impacts of CE models on the value chain, but also its implications for sustainability. In fact, a broader framework also enables a better assessment from a triple bottom line (i.e., people-planet-profit) perspective [9], which we shall term, in accordance with Breyer's [10] theory, acquisitive efficiency, social effectiveness, and environmental effectiveness. 
Interestingly, in marketing, both the theoretical and conceptual tools to adopt a broader orientation, such as the institutional school of thought [11], as CE necessitates, are already in place. They have been developed several decades ago. These existing theories can describe new phenomena, such as $\mathrm{CE}$, and equip scholars with useful analytical tools for a more comprehensive understanding of the topics of relevance for the study of CE's theoretical impact on the sustainability of value chains.

Accordingly, we draw on classic theories from the institutional school of thought in marketing, in general, and Breyer's [10] electric theory of marketing [11], in particular, to answer the following research questions: (1) How does the collaborative economy transform the conventional business paradigm? (2) What is the theoretical impact of the CE on the value chain? And (3) what is the potential of the $\mathrm{CE}$ for achieving sustainability in the value chain? The institutional thought in marketing suggests that any "concern", or organization is simultaneously a buyer and a seller, or as in Breyer's [10] words, a "deficit" and an "excess". The acknowledgement of an intermingling, rather than a distinction between production and consumption, makes Breyer's theory particularly suitable for the study of the CE.

\section{The Macro Perspective of Business and Marketing}

The conceptualization of $\mathrm{CE}$ is still being debated to this day. Some authors [12,13] conflate the notion of $\mathrm{CE}$ with that of collaborative economy platform, with Uber being part of a digital platform economy, while others acknowledge that "collaborativity" can be found in a variety of contexts, including offline settings [1,14]. We reconcile both perspectives by considering the CE as an umbrella term that comprises both offline and online delineation [1,14], and categorize Uber as part of the online delineation of the $\mathrm{CE}$, which can be termed the digital platform economy [12,13]. As such, CE: (1) entails many forms of practices; (2) draws on online, mobile, and social technologies for broader scale and scope; (3) efficiently circulates resources originating from "individual consumers", that are redistributed or mutualized directly to obtainers or indirectly to them by means of one or more intermediary(ies) [12,13]. Table 1 shows how the CE departs from the conventional business model. In essence, the CE can best be viewed as a "resource circulation system" [15,16], more inclusive of consumers in "crowd-based capitalism" [17]. Marketing in this broader system is a means to circulate those resources more efficiently. This was the prominent view that was originally held in the institutional school of thought of marketing, in general, and by some of its early theorists with the likes of Breyer [10] and his electric theory of marketing, in particular. This broader perspective is, therefore, more suitable to the study of the $\mathrm{CE}$ than the more firm-centric perspective of the conventional business paradigm (see Table 1).

Table 1. The contemporary business paradigm and the broadened business paradigm as induced by the collaborative economy.

\begin{tabular}{ccc}
\hline & Contemporary Business Paradigm & Broadened Business Paradigm \\
\hline $\begin{array}{c}\text { Perspective } \\
\text { Orientation }\end{array}$ & Micro & Macro \\
Value creation & Managerial & $\begin{array}{c}\text { Societal } \\
\text { Resources }\end{array}$ \\
Actors & $\begin{array}{c}\text { New product or professional service } \\
\text { Organizations (mostly for-profit), } \\
\text { employees and passive consumers }\end{array}$ & $\begin{array}{c}\text { Pre-owned resources or individuals' skills and services } \\
\text { Organizations (for-profit and not-for-profit), employees, } \\
\text { proactive two-sided consumers, government }\end{array}$ \\
Networks & Discrete perspective (dyadic systems) & Continuous perspective (resource circulation systems) \\
\hline
\end{tabular}

\section{The Electric Theory of Marketing}

In line with the institutional school of thought in marketing, Breyer's [10] electric theory of marketing is an analogy with the circuit of electricity. The understanding of a consumer and a producer is much broader and macro-oriented than the current narrower and managerially-oriented business perspective [11]. Breyer [10] clearly stresses that the producer-consumer dyad is merely a notion of 
perspective. Both are sides of the same coin. While Breyer focuses mostly on organizations, his generic theory singles out any "concern" or individual, as being able to be either in a buying or in a producing function. This early conceptualization converges with the empirical evidence observed in the CE involving therefore "two-sided consumers" [14]. In contrast to Breyer [10], however, the CE is not merely focused on monetized exchanges but on all types of exchanges, including barter (which he says marginal) and gift-giving (which he does not cover at all) [18]. Also, the CE is not limited to physical goods, but extends to any type of resource and service [18]. The CE broadens Breyer's [10] initial theory without disproportionally denaturing it otherwise.

The following sections explain the electric theory of marketing which is then applied to a famous CE player, Uber, in order to assess how the CE theoretically impacts the value chain (RQ1).

\subsection{The Concept of Markets}

According to Breyer [10], the notion of market is all too often restrictive in that it narrows down to the demand side. To him, the market refers more accurately to the supply side and its nexus, the supply chain:

"The business person customarily uses the term market as synonymous with the term demand. They speaks of the 'market' for their goods, i.e., the demand. This is unfortunate since it fails to give due emphasis to supply." (p. 54)

Consequently, he defines a market as an opportunity between a buyer and seller to close an active exchange in the following terms:

"A market is nothing more than the opportunity to buy or sell, i.e., to exchange goods; it is an opportunity rather than an actual purchase or sale, in the sense that there exists a supply of merchantable goods in the hands of certain prospective sellers who would like to dispose of their goods for a consideration, and on the other hand, there are a number of prospective buyers with a supply of money or its equivalent who would like to obtain goods of the general nature of those held by the prospective seller and would likely surrender some of their means to do so." (p. 54)

It is unfortunate that the conflating of demand with the notion of market prevails up to this day. Breyer's [10] conceptualization brings to the fore the fact that a market is a mere opportunity to buy and sell, and applying his definition of markets to the CE involves semantic adjustments but the fundamental tenets remain unaltered. First, the opportunity expands from buy-sell to the broader notion of exchange. Second, the market involves not only goods but all types of resources including services. Third, the seller (buyer) is more broadly a(n) provider (obtainer) of goods or services for free, at a fee, or for any other compensation.

\subsection{The Deficit and Surplus Side of Markets}

Marketing's role is to convert opportunities into active exchange of goods, since "this agency is the marketing machinery" [10] (p. 65). More specifically, that conversion occurs between a "deficit side" (i.e., demand) (p. 69) and a "surplus side" (p. 83). Matching both is highly contingent upon time, place, and competition, as opportunities to enact exchanges vary with temporal fluctuations, geographic dispersion, and competitive intensity. Therefore, any system which attenuates these contingencies will more efficiently match the deficit side and the surplus side of markets, thereby realizing the fundamental aim of marketing. Spatio-temporal coordination was later highly emphasized in Felson and Spaeth's [19] work, which initially coined the concept of "collaborative consumption".

\subsection{Marketing Circuits}

To Breyer [10], the potentials to buy and sell are similar to the potentials in electricity, and he conceptualized sellers and buyers as batteries generating flows of electric current. This current is the 
actual "sale-purchase transaction". Three key concepts borrowed from the electricity jargon define marketing circuits, namely poles, conductors, and marketing circuit closure.

\subsubsection{Poles}

As shown in Figure S1 (see supplementary material), a positively-charged pole in juxtaposition of a negatively-charged pole creates a potentiality of producing electric power. In markets, persons or concerns in their producing (consuming) capacities are positive (negative) poles building up surplus, and creating things (destroying things to satisfy deficits). Poles create exchange value in as much as they are connected, typically under varying intensity. The connection of positive and negative poles creates the potentials making up markets. The intensity of positive charges depends on labor, land, capital sacrifices, and selling power, whereas the intensity of negative charges depends on wants and purchasing power.

\subsubsection{Conductors}

Contact. In markets, the positive (negative) pole is split into distinct sections, each having a charge of its own, representing the supply (demand) force of a different resource. Antennas of both supply and demand move, therefore, in search for each other. Breyer [10] stresses that this contact process entails all the ways and means employed by consumers to search out desired resources, and sources thereof. In the CE, this quest is not limited to new goods but extends naturally to second hand goods [20], any type of resources, and especially personal services [17].

Negotiation. Antennas of positive pole may touch that of negative pole. A negotiation process initiates, where buyers and sellers discuss quality, price, etc. If contact occurs and negotiation starts, the charges are affected, even if contact is broken and the circuit is not closed.

\subsubsection{Marketing Circuit Closure}

As shown in Figure S2 (see supplementary material), the negotiation process continues until, at some point, agreement is reached. At this point, a current occurs in three flows. The flow of order is related to the contact and negotiation functions. The flow of goods involves the storage, measurement, packing, financing, and risk-bearing functions, and at varying degrees, depending upon the industry. The flow of payment, if money is paid, involves the payment function. When these three flows are consummated, the sale-purchase transaction is complete and the marketing circuit closed.

Figure S3 (see supplementary material) shows how poles interact with each other in an intermediated marketing circuit involving a producer, a wholesaler, a retailer, and a consumer. The electric theory of marketing frames eloquently the marketing circuit as a resource circulation system in which each agent is a "node" [21] acting dualistically; as a producing capacity with a positive pole and as a consuming capacity with a negative pole. This dualism applies to both formal organizations and to individual consumers. Individuals may thus have a producing capacity and a potential of contributing to value creation as an individual consumer, in addition or in lieu of a formal employee role.

\section{Application of the Electric Theory of Marketing to the Collaborative Economy: Description of the Theoretical Impact of the Collaborative Economy on the Value Chain of Transportation Services}

We shall next demonstrate how the electric theory of marketing offers a detailed understanding of the CE's theoretical impact on the value chain of services. We use the specific case of Uber, one of the flagships of the CE [22], because it represents the CE ideal or nightmarish form of capitalism [23], by combining the foundational cores of "community", "access", and digital "platform" [24] with profit.

By examining the process involving the driver (positive pole) and the user (negative pole), we demonstrate how Uber theoretically impacts the value chain by contributing superiorly to 
marketing circuit closure, through improved flow of order, service, and payment, thereby explaining its edge in value creation [25] and marketing agency [10] (p. 4) in the service value chain.

\subsection{The Concept of Markets and the Deficit and Supply Sides of Markets in the Collaborative Economy}

It is now well-known that technology facilitates exchanges of all types. The computer, the Internet, mobile, Internet of Things, blockchain, and social networking technologies have brought about the much needed spatio-temporal coordination of exchange activities, which was at dearth at the time of Breyer [10] or Felson and Spaeth [19]. An innovative mobile application, such as Uber, draws on technology to put hailers directly in contact with drivers, circumventing traditional taxi dispatching systems, rendering them irrelevant middlemen in the transportation supply chain [26]. In addition, the special status of the drivers, as autonomous workers not formally employed by Uber, lowers the price of the rides [27]. Uber therefore combines increased spatio-temporal effectiveness with price-based competitive advantage [28]. From this viewpoint, Uber provides superior agency, as it matches more effectively deficit and supply sides of the market; it converts more effectively opportunities into active exchange of service. Since Breyer [10] equates this agency with the marketing machinery, it follows that a service like Uber contributes more effectively to the marketing machinery through an increased supply chain efficiency.

\subsection{Marketing Circuits: Poles, Conductors, and Marketing Circuit Closure}

\subsubsection{Poles and Conductors}

Any individual with a driver's license can become a self-employed driver. Leaving aside the obviously debatable aspects entailed by such a status [3,23,29], the Uber business model increases consumers' positive (production) pole. By so doing it may supposedly contribute to "job creation" and enhance purchasing power notably in sluggish economic conditions [30]. For example, if the individual was unemployed or under-employed, he had a surplus in his production capacity. This excess is less well absorbed in a mature job market, which suffers from systemic unemployment. Uber constitutes an opportunity to gainfully and efficiently channel that surplus supply side to a deficit side. Besides, since the driver's positive and negative poles are interrelated, an increase in the individual's positive pole will shift his negative pole upwards as well. First, the activity may increase the driver's purchasing power (positive charges). Second, working for Uber as a driver may entail a wide array of additional personal wants as well as demands from the side of Uber, such as an upgraded car, related maintenance services, insurance, gas expenditures, electronic devices (e.g., smartphone), and so on (negative charges). On the other hand, users or obtainers are negatively-charged poles whose wants and purchasing power increase intensity.

\subsubsection{Marketing Circuit Closure}

Uber improves the flow of orders. Before the advent of Uber, users seeking motorized transportation services had usually the choice between a limited set of options, including taxis, public transportation, and co-riding schemes. The advent of Uber (and others) increased the number of supply segments by including individuals themselves as positive poles. With public transportation, users faced rigid schedules and venues. The service does not necessarily depart or arrive at the time desired by the user; nor does it necessarily transport the user to the desired location. With taxis, spatio-temporal coordination is increased, but users dealt with dispatchers and a legally limited set of licensed taxi drivers, which increased waiting time and created monopolies. Co-riding services solve the spatio-temporal coordination issue, as well as the dispatcher issue, but these early collaborative models operated on websites with insufficient critical mass to connect enough positive poles to negative poles, thus remaining inefficient. Uber draws on mobile and GPS technology, as well as tremendous amounts of venture capital, to connect more efficiently the users' negative moving antennas to the drivers' positive moving antennas, than the taxi industry (including dispatcher), public transportation, 
or co-riding schemes. The quick achievement of critical mass bolstered Uber as an attractive alternative to match demand and supply. Thus, it made the flow of order much faster by increasing exchange opportunities in the exact quantity, time, and place desired by the user.

Uber improves the flow of services. Public transportation faces infrastructure issues, strikes, incivilities, and user carelessness, which dampen service quality. Enjoying monopolies in the personal transportation business, the uncompetitive nature of the taxi industry has often been thought to account for its supposedly poor service. In co-driving, the driver is typically subject to limited or nil levels of control, rendering service quality unpredictable and erratic. Besides, co-driving entails limited procedures for user complaints. In contrast, in addition to critical mass, the implementation of highly efficient reputation systems lie at the core of the success of web-mediated collaborative models [18]. Self-employed drivers are prompted to provide top-level service in order to earn themselves a good reputation online, with high user ratings and positive comments. Uber also imposes certain standards, such as opening doors for passengers and providing them with free gifts, such as sweets or a bottle of water. The fact that they are self-employed certainly makes the matter of service even more important. It is as if each driver competes with others to earn the most business, trying to put his "profile or brand" to the fore. In tech-mediated environments, the evaluation of service quality lies heavily on ratings directly related to user experience. Therefore, Uber improves the flow of services by offering, in principle, superior service. In addition, Uber recently extended its business activities to include food delivery with UberEATS. These additional services increase users' negative charge, as it instills more wants. The fulfillment of these additional wants shall thus entail additional efficient flows of food delivery services, but also influence the firms originally active in that business.

Uber improves the flow of payments. Taxis and co-riders may have "cash only" policies, while public transportation may only accept cash or upfront subscriptions of some sort (e.g., monthly). This is a barrier for users who carry little cash, carry no cash at all, or did not get a subscription beforehand. The taxis and public transportation tariffs are also based on rigid price structures, which may be overor underpriced. Uber's mobile payment renders the flow of payments quicker and easier to process. The dynamic pricing algorithm also relieves the burden of pricing and negotiating from drivers. Hence, dynamic pricing increases profitability by dynamically adjusting prices based on a multiplicity of factors to get the most accurate price for the user and optimal profit levels for Uber. Despite the effective nature of dynamic pricing, some concerns related to Uber's surge pricing practices, as well as drivers surging the price themselves [30], hinder proper payment flows.

Uber improves marketing circuit closure. Overall, by improving the flow of order, services, and payments between more stimulated positive and negative poles, Uber contributes to closing of the marketing circuit more efficiently than taxis, public transportation, and carpooling schemes altogether. Furthermore, Uber closes additional circuits (gaps) which could not be possibly closed by these conventional transportation schemes. As such, Uber realizes better the marketing goal of "getting goods of the right quality, quantity, and price to those needing them in the most efficient manner possible" [10] (p. 212). As will be explained later, this increased efficiency, essentially enabled by technology advances, does not go without ethical issues, especially with regards to data collection and privacy, as well as fairness in surge pricing and driver's rights, to name but a few. A more normative assessment of Uber will determine the extent to which the CE truly contributes to sustainability in the value chain.

\section{Normative Considerations and Perspectives on Collaborative Marketing Circuits for Sustainable Transportation Value Chains}

The institutional perspective in marketing emphasizes that descriptive analysis of marketing circuit close (see Sections 3 and 4) should always be complemented by a critical or prescriptive analysis, which assesses the overall business contribution to society [10], and potentially also sustainability. Accordingly, we now elaborate on the normative considerations surrounding the $\mathrm{CE}$ in order to assess its implications for sustainability in the value chain. We therefore discuss below the notions 
of acquisitive efficiency and social effectiveness, two core objectives which marketing circuits should strive for according to Breyer's [10] theory. We show that Uber only partially fulfills these, hence its controversial status. From an institutional marketing perspective, Uber thus needs reformation to truly embody a sustainable chain of value.

\subsection{Acquisitive Efficiency}

Acquisitive efficiency relates to the notion of private profits. This efficiency is influenced by the profit opportunity, merchandising acumen, and operating technique. First, the profit opportunity is very salient in a business model like Uber, since it eliminates dispatchers and does not have patronal charges and employee benefits, due to the self-employed status of its drivers. In fact, returns on investment increase for private investors, hinting at the superior profit opportunity [31]. Second, Travis Kalanick and Garrett Camp, founders of Uber, showed tremendous trading acumen, as they were able to identify a market gap after an unpleasant taxi ride while they were attending LeWeb conference in Paris in 2008 [32]. At that moment, they were able to "interpret the market facts in terms of future results" [10] (p. 189). But this is far from enough. Third, and most importantly, the previous section detailed how Uber's emphasis on technology improves the flow of orders, services, and payments contributing to improve operating technique.

To Breyer [10], acquisitive efficiency should occur within the limits of the law. This was a crucial notion for thinkers of his time, as marketing scholars wrote law appraisals or policy guidance notes, and a third of marketing papers were written by government officials [11]. A monetized service like Uber is problematic because it operates in grey zones and under legal loopholes [29]. The service has faced "considerable resistance and criticism for opening up unregulated peer-to-peer marketplaces with adverse social impacts" [23] (p. 149), but mostly from the taxi industry rather than consumers. Some scholars even went as far as to advise Uber on how it may "win over regulators" [33]. This is not so surprising considering the micro and managerial orientation induced by the current business paradigm. In fact, these are managerial recommendations, mostly relevant for firms, but fail to consider the implications-whether social or environmental—of a service like Uber, despite its inherent benefits for markets. Others stressed that disruption—not to say illegality—is often necessary to move innovation forward and advance from inefficiency to efficiency [34]. Anyhow, from a purely Breyerian perspective, Uber may only partially demonstrate acquisitive efficiency due to its deliberate non-compliance with the law.

\subsection{Social Effectiveness}

Breyer states that determining specific criteria for social effectiveness is difficult. Whether speaking of public welfare, public interest, or social gain, it is hard to capture such a concept in a single metric, such as acquisitive efficiency, in profit and conformance to the law.

CE models, such as Uber, do have social benefits. For example, they present opportunities for individuals to find temporary employment, generate extra income, enhance social interactions, and access resources otherwise not attainable, more especially in contexts of economic decline and among disadvantaged communities [35]. Yet, it is also fair to say that the controversies surrounding the big players of the CE such as Uber, in particular, are a testimony of relative social ineffectiveness $[29,36]$. We shall name but a few of such issues.

From a provider perspective, the status of self-employed workers is more disadvantageous to workers than the status of employees, as it nullifies traditional remuneration and corporate benefits, while generating income subject to no legal minimum [37]. To further show the limits of Uber's social effectiveness, the firm plans to replace all of the drivers by a fleet of autonomous vehicles. Apart from the additional unemployment that such automation will produce, it is questionable to what extent Uber remains collaborative. We would move from a peer-to-peer configuration, where a user can be provider and vice-versa, back to a business-to-consumer configuration again. Individuals would not intervene as providers and be reduced to a user role, unless they may themselves provide autonomous 
vehicle fleets to others, for example. Anyhow, in light of the electric theory of marketing, this will affect to some extent individuals' production activities by diminishing their positive production charges.

From an obtainer perspective, dealing with informal, unprofessional service providers generates fraud, liability, hygiene, or safety issues [38], even when reputation systems are at work [39]. Dealing with robots may partially settle some of these issues but create others, such as technical or privacy issues, while further dehumanizing the brand and the socialization aspect that was supposed to lie at the core to the $\mathrm{CE}[14,15,18]$. Obtainers' negative charge will be dampened by bad service experiences and less likely to load again for similar services.

Overall, there will be less demand and supply looking for market circuit closure, which enable exchange and profit. While market circuit closure refers to acquisitive efficiency, this type of efficiency ensures social effectiveness [10]. Hence, from a social effectiveness perspective, Uber is by no means exemplary.

\subsection{Environmental Effectiveness}

In addition to purely acquisitive or social effectiveness, ecological considerations have increased in importance and sustainability, unknown in Breyer's time, which has become quintessential today. Following the triple bottom line framework [9], sustainability needs balance in three core dimensions: economic (profit), social (people), and environmental (planet) [9]. Acquisitive efficiency and social efficiency conflate with the economic and social dimensions, respectively. This section elaborates on the environmental effects of Uber following Schrader's [40] classification that distinguishes efficiency effects, sufficiency effects, and rebound effects.

Efficiency effects is gained when the input of environmental resources results in more uses of the product, or when a given number of product used is realized with a lower environmental cost [41]. Uber is likely to generate both effects.

One of the most obvious effects of Uber is car use intensification as the number of uses of a specific car increases during the lifetime of the car [42]. In fact, car-sharing could substitute up to seven cars [43]. However, the positive effect of use intensification is also counterbalanced by a negative effect on car life expectancy [44]. Consumer Reports states that the average life expectancy of a new vehicle is around eleven years, or 200,000 miles [45]. This distance can be achieved in 10 years under normal usage (e.g., family) or 2 years under a usage intensive service like Uber. On the one hand, Uber enables exploitation of the full potential of cars before they are disposed of, but on the other hand the increased usage is merely the shrinkage of the normal life expectancy of the car.

Sufficiency effects refer to the satisfaction gained with a reduced use of products and services [46]. The sufficiency effects lie actually at the crux of environmental effects of Uber and the likes, much more than efficiency effects $[47,48]$. The resource efficiency inherent to services like Uber could contribute to more sufficient ways of consumption on both a macro level [49] and on individual level [50]. For example, if consumers have to pay per car use rather than only or mainly when purchasing a car, they tend to reconsider their desire to use. More specifically, if a consumer considers the full price of driving, as expressed in the car sharing price per hour or kilometer, the consumer will be more likely to use public transportation than a car owner who only considers gas expenditure [43]. Therefore, the longer that they use carsharing services like Uber, the more consumers decrease their driving.

The total ecological effects of Uber can only be realistically assessed by considering rebound effects as well. Both the eco-efficiency accruing from efficiency and sufficiency effects could lead to a situation of increased resource use. In such a case, the additional used resources might even exceed the savings and nullify the efficiency gains [44]. Rebound effects mean that "more resource-efficient products and services, as well as the increase in resource efficiency in production, do not lead to a decline in resource consumption in macroeconomic terms if they are overcompensated by volume effects, or in other words, when the rising demand for a product increases the volume of the products on the market" [51] (p. 185). Car-sharing services like Uber could contribute to abundance and increased number of car travels made. The lower price of Uber could also allow consumers with moderate income to use 
transportation services, similar to a taxi, which are otherwise unaffordable to them. In sum, this could actually lead to additional use of environmental resources as well as increased $\mathrm{CO}_{2}$ emissions and pollution from broken cars or parts, thus causing the rebound effect.

The environmental effectiveness of Uber is, therefore, partial. While sufficiency gains are evident, they are attenuated by partial efficiency gains and potential rebound effects. Similar results have been found in the collaborative fashion industry as well [44], and in "use-rather-than-owning" strategies within collaborative consumption [51].

\section{Discussion: Perspectives on the Potential of the Collaborative Economy for Sustainability in the Value Chain}

Our discussion of the social (and environmental) effectiveness of the $\mathrm{CE}$ is biased by the vignette we chose. Different results might be obtained with time banks, peer-to-peer toy-lending libraries, or donation centers. In fact, such models better embody the $\mathrm{CE}$ as a new pathway to sustainability and social effectiveness while yielding merely decent acquisitive efficiency. Yet, they are not necessarily acknowledged as being part of the CE by some researchers in the CE research field [17]. In the case of Uber-related models, the most conclusive aspect about their social effectiveness is that a sustainable and socially effective transformation requires more than just operating technological and organizational changes [49]. In addition to those, social change, adaptation, and design processes must also be taken into account, such as regulation, policy frameworks, and consumer interests [52]. Schor [53] warns that these may only be considered if the ownership and governance of the platforms is democratized. In fact, as Georg Simmel [54] posited, politics create the market rather than the reverse. It follows that settling regulatory issues surrounding the $\mathrm{CE}$ is a sine qua non condition for implementing a collaboratively infused market that benefits the many rather than a few private stockholders-hence, realizing social effectiveness. However, this requires political courage and vision.

It is worth mentioning that to Breyer [10], social effectiveness is superior to acquisitive efficiency, although the latter propels the former. His book was replete with analyses of policy frameworks, especially the New Deal, which reflects the consideration that scholars of the day had for higher-order contingencies related to the market, and which are inherently of ethical substance, such as government's role in the marketing system [55,56], appraisal of government regulation [57-59], misuse of fear and immoral image appeals in advertising, as well as excessive number of middlemen [10], aggressive salesmanship [59], questionable product quality, insufficient standards, and needs for greater consumer protection [60].

The positive theoretical impact of the $\mathrm{CE}$ to value chain sustainability would more likely be achieved by complementing profitability analysis and resource efficiency with considerations for social effectiveness and environmental effectiveness. This will require adopting a scholarly posture closer to that which characterized the institutional school of thought in marketing in general, and the electric theory of marketing in particular, such as the appraisal or proposition of legislation or taxation expected to attenuate controversies in the CE. Regulation and governance should be considered again as pivotal elements of the value chain. The issues related to user protection need to be coupled with those of provider protection. More research is needed on how to accomplish both acquisitive efficiency and social effectiveness objectives in the value chain simultaneously. Finally, sustainability is pivotal, and future research needs to dig deeper into the social topics rising in importance, such as artificial intelligence and automation, which may suppress the need for a human provider in the value chain.

Supplementary Materials: The following are available online at http:/ /www.mdpi.com/2071-1050/11/2/390/s1.

Author Contributions: For research articles with several authors, a short paragraph specifying their individual contributions must be provided. The following statements should be used "conceptualization, M.E. and E.S.

Funding: This research received no external funding.

Acknowledgments: In this section you can acknowledge any support given which is not covered by the author contribution or funding sections. This may include administrative and technical support, or donations in kind (e.g., materials used for experiments). 
Conflicts of Interest: The authors declare no conflict of interest.

\section{References}

1. Schor, J.B.; Fitzmaurice, C.J. Collaborating and connecting: The emergence of the sharing economy. In Handbook of Research on Sustainable Consumption: Northampton; Reisch, L.A., Thøgersen, J., Eds.; Edward Elgar: Northampton, MA, USA, 2015; pp. 410-425.

2. PricewaterhouseCoopers. The Sharing Economy; Consumer Intelligence Series; PwC: New York, NY, USA, 2015.

3. Morozov, E. The 'Sharing ECONOMY' Undermines Workers Rights, 2013. Available online: http:// evgenymorozov.tumblr.com/post/64038831400/the-sharing-economyundermines-workers-rights (accessed on 14 December 2018).

4. Ritzer, G. Prosumer capitalism. Sociol. Q. 2015, 56, 413-445. [CrossRef]

5. Lambert, C. Shadow Work: The Unpaid, Unseen Jobs That Fill Your Day; Counterpoint: New York, NY, USA, 2015.

6. Prahalad, C.K.; Ramaswamy, V. Co-creation experiences: The next practice in value creation. J. Interact. Mark. 2004, 18, 5-14. [CrossRef]

7. Vargo, S.L.; Lusch, R.F. Evolving to a new dominant logic for marketing. J. Mark. 2004, 68, 1-17. [CrossRef]

8. Perret, B. De la propriété à l'usage. Esprit 2015, 7, 30-39. [CrossRef]

9. Elkington, J. Enter the triple bottom line. In The Triple Bottom Line; Elkington, J., Ed.; Routledge: London, UK, 2013; pp. 23-38.

10. Breyer, R.F. The Marketing Institution; McGraw-Hill: New York, NY, USA, 1934.

11. Wilkie, W.L.; Moore, E.S. Scholarly research in marketing: Exploring the " 4 eras" of thought development. J. Public Policy Mark. 2003, 22, 116-146. [CrossRef]

12. Fuster Morell, M.; Espelt, R. A Framework for Assessing Democratic Qualities in Collaborative Economy Platforms: Analysis of 10 Cases in Barcelona. Urban Sci. 2018, 2, 61. [CrossRef]

13. Fuster Morell, M. Sharing Cities: A Worldwide Cities Overview on Platform Economy Policies with a Focus on Barcelona; Sehen-Editorial UOC: Barcelona, Spain, 2018.

14. Ertz, M.; Durif, F.; Arcand, M. Collaborative consumption: Conceptual snapshot at a buzzword. J. Entrep. Educ. 2016, 19, 1-23. [CrossRef]

15. Ertz, M.; Durif, F.; Arcand, M. A conceptual perspective on collaborative consumption. Acad. Mark. Sci. Rev. 2018. [CrossRef]

16. Arnould, E.J.; Rose, A.S. Mutuality: Critique and substitute for Belk's "sharing". Mark. Theory 2016, 16, 75-99. [CrossRef]

17. Sundararajan, A. The Sharing Economy: The End of Employment and the Rise of Crowd-Based Capitalism; MIT Press: Cambridge, MA, USA, 2016.

18. Botsman, R. Defining the Sharing Economy: What Is Collaborative Consumption-And What Isn't. Fastcoexist.com, 27, 2015. Available online: https://www.fastcompany.com/3046119/defining-the-sharingeconomy-what-is-collaborative-consumption-and-what-isnt (accessed on 28 December 2018).

19. Felson, M.; Spaeth, J.L. Community structure and collaborative consumption: A routine activity approach. Am. Behav. Sci. 1978, 21, 614-624. [CrossRef]

20. Chu, H.; Liao, S. Exploring Consumer Resale Behavior in C2C Online Auctions: Taxonomy and Influences on Consumer Decisions. AMS Rev. 2007, 11, 1-25.

21. Gansky, L. The Mesh: Why the Future of Business Is Sharing; Penguin: New York, NY, USA, 2010.

22. Robertson, T.S. Business model innovation: A marketing ecosystem view. AMS Rev. 2017, 7, 90-100. [CrossRef]

23. Martin, C.J. The sharing economy: A pathway to sustainability or a nightmarish form of neoliberal capitalism? Ecol. Econ. 2016, 121, 149-159. [CrossRef]

24. Acquier, A.; Daudigeos, T.; Pinkse, J. Promises and paradoxes of the sharing economy: An organizing framework. Technol. Forecast. Soc. Chang. 2017, 125. [CrossRef]

25. Gundlach, G.T. The American Marketing Association's 2004 definition of marketing: Perspectives on its implications for scholarship and the role and responsibility of marketing in society. J. Public Policy Mark. 2007, 26, 243-250. [CrossRef]

26. Pepić, L. The sharing economy: Uber and its effect on taxi companies. Acta Econ. 2018, 16, 123-136. [CrossRef] 
27. Schneider, H. Creative Destruction and the Sharing Economy: Uber as Disruptive Innovation; Edward Elgar Publishing: New York, NY, USA, 2017.

28. Tomassetti, J. Does Uber Redefine the Firm: The Postindustrial Corporation and Advanced Information Technology. Hofstra Labor Employ. Law J. 2016, 34, 1-78.

29. Slee, T. What's Yours Is Mine: Against the Sharing Economy; OR Books: New York, NY, USA, 2015.

30. Hall, J.V.; Krueger, A.B. An Analysis of the Labor Market for Uber's Driver-Partners in the United States; No. w22843; National Bureau of Economic Research: Cambridge, MA, USA, 2016.

31. Bloomberg. Lyft Is Gaining on Uber as It Spends Brig for Growth, 2016. Available online: http:/ / www. bloomberg.com/news / articles / 2016-04-14/lyft-is-gaining-on-uber-as-it-spends-big-for-growth (accessed on 21 June 2016).

32. Business Insider. Inside the Crazy-Successful, Controversial Life of Billionaire Uber CEO Travis Kalanick. Business Insider, 4 May 2017. Available online: http:/ / www.businessinsider.com/life-of-uber-ceo-traviskalanick-2017-5 (accessed on 16 December 2017).

33. Cannon, S.; Summers, L.H. How Uber and the sharing economy can win over regulators. Harvard Bus. Rev. 2014, 13, 24-28.

34. Guttentag, D. Airbnb: Disruptive innovation and the rise of an informal tourism accommodation sector. Curr. Issues Tour. 2015, 18, 1192-1217. [CrossRef]

35. Dillahunt, T.R.; Malone, A.R. The promise of the sharing economy among disadvantaged communities. In Proceedings of the 33rd Annual ACM Conference on Human Factors in Computing Systems, Seoul, Korea, 18-23 April 2015; pp. 2285-2294.

36. Murillo, D.; Buckland, H.; Val, E. When the sharing economy becomes neoliberalism on steroids: Unravelling the controversies. Technol. Forecast. Soc. Chang. 2017, 125, 66-76. [CrossRef]

37. Summers, L.H.; Balls, E. Report of the Commission on Inclusive Prosperity; Center for American Progress: Washington, DC, USA, 2015; Available online: https:/ / cdn.americanprogress.org/wp-content/uploads / 2015/01/IPC-PDF-full.pdf (accessed on 21 June 2016).

38. Ranchordás, S. Does sharing mean caring: Regulating innovation in the sharing economy. Minn. J. Law Sci. Technol. 2015, 16, 413.

39. The Independent. Uber Agrees to Settle US Lawsuit Filed by India Rape Victim, 2017. Available online: http:/ / www.independent.co.uk/news/world/americas/uber-rape-india-driver-us-lawsuit-delhimedical-records-court-case-law-suit-a8100911.html (accessed on 16 December 2018).

40. Schrader, U. Konsumentenakzeptanz Eigentumsersetzender Dienstleistungen: Konzeption und Empirische Analyse; Lang: Frankfurt am Main, Germany, 2001.

41. Hinterberger, F.; Luks, F.; Schmidt-Bleek, F. Material flows vs. natural capital: What makes an economy sustainable? Ecol. Econ. 1997, 23, 1-14. [CrossRef]

42. Edelman, B.G.; Geradin, D. Efficiencies and regulatory shortcuts: How should we regulate companies like Airbnb and Uber. Stanf. Technol. Law Rev. 2015, 19, 293-326. [CrossRef]

43. Firnkorn, J.; Müller, M. What will be the environmental effects of new free-floating car-sharing systems? The case of car2go in Ulm. Ecol. Econ. 2011, 70, 1519-1528. [CrossRef]

44. Iran, S.; Schrader, U. Collaborative fashion consumption and its environmental effects. J. Fash. Mark. Manag. 2017, 21, 468-482. [CrossRef]

45. Consumer Reports. Make Your Car Last 200,000 Miles. Consumer Reports, 6 November 2018. Available online: https:/ / www.consumerreports.org/car-repair-maintenance/make-your-car-last-200-000-miles / (accessed on 24 December 2018).

46. Figge, F.; Young, W.; Barkemeyer, R. Sufficiency or efficiency to achieve lower resource consumption and emissions? The role of the rebound effect. J. Clean. Prod. 2014, 69, 216-224. [CrossRef]

47. Meijkamp, R. Changing consumer behaviour through eco-efficient services: An empirical study of car sharing in the Netherlands. Bus. Strategy Environ. 1998, 7, 234-244. [CrossRef]

48. Chatterjee, K.; Andrews, G.; Ricci, M.; Parkhurst, G. Qualitative insights into the effect on travel behavior of joining a carshare. Transp. Res. Rec. 2013, 23, 76-84. [CrossRef]

49. Mont, O.; Dalhammar, C.; Jacobsson, N. A new business model for baby prams based on leasing and product remanufacturing. J. Clean. Prod. 2006, 14, 1509-1518. [CrossRef]

50. Speck, M.; Hasselkuss, M. Sufficiency in social practice: Searching potentials for sufficient behavior in a consumerist culture. Sustain. Sci. Pract. Policy 2015, 11, 14-32. [CrossRef] 
51. Leismann, K.; Schmitt, M.; Rohn, H.; Baedeker, C. Collaborative consumption: Towards a resource-saving consumption culture. Resources 2013, 2, 184-203. [CrossRef]

52. Söderholm, P.; Tilton, J.E. Material efficiency: An economic perspective. Resour. Conserv. Recycl. 2012, 61, 75-82. [CrossRef]

53. Schor, J. Debating the sharing economy. J. Self-Gov. Manag. Econ. 2016, 4, 7-22.

54. Simmel, G. The Philosophy of Money; Bottomore, T.; Frisby, D., Translators; Routledge: London, UK, 1907. First published 1990.

55. Clark, F.E. Principles of Marketing; Macmillan Co.: London, UK, 1922.

56. Duddy, E.A.; Revzan, D.A. Marketing: An Institutional Approach; McGraw-Hill: New York, NY, USA, 1947.

57. Engle, N.H. Implications of the Robinson-Patman Act for marketing. J. Mark. 1936, 1, 75-81. [CrossRef]

58. Grether, E.T. Fair trade legislation restricting price cutting. J. Mark. 1937, 1, 334-354. [CrossRef]

59. Maynard, H.H.; Walter, C.W.; Beckman, T.N. Principles of Marketing; Ronald Press Co.: New York, NY, USA, 1927.

60. Philips, C.F. Marketing; Houghton Mifflin: New York, NY, USA, 1938.

(C) 2019 by the authors. Licensee MDPI, Basel, Switzerland. This article is an open access article distributed under the terms and conditions of the Creative Commons Attribution (CC BY) license (http:/ / creativecommons.org/licenses/by/4.0/). 